\title{
New Public Management and Public Sector Reform in a Non-Competitive Environment
}

\author{
Ali Rkein \\ Asia Pacific College of Business and Law \\ Charles Darwin University \\ Darwin, Australia
}

\begin{abstract}
This paper seeks to explore the public sector reform within the ideals of the NPM in a unique and special context characterised by a non-competitive market. Whereas extant literature focuses on the adoption of NPM in the process of public sector reform, no prior study has looked at this concept in a non-competitive market. An understanding of the workings of the NPM in such environment where contestability does not exist is fundamental to policy makers and researchers. This study examines the workings of the NPM in a non-competitive market and provides supportive evidence of the necessity of market forces to achieve the intended benefits from the adoption of NPM in public sector reform. The study shows that although the Government justified its adoption of the NPM on the basis of rationalizing public sector management, the reality was far from satisfactory. The paper shows a limited significance of NPM in improving the performance of public sector agencies due to the non-competitive environment.
\end{abstract}

Keywords Public sector, reform, NPM, non-competitive, Australia

\section{Introduction}

The public sector around the world has been under scrutiny for a long period and its reform has always been of great importance to governments, public and researchers. However, the failure of the public sector around the world to respond adequately to some financial crises in the 1970 s and to the problems of maintaining economic growth has made the reform inevitable (Ferlie at al., 1996; Funnell and Cooper, 1998; Hopwood, 1992, 2000; Miller, 1992, 1994; Rkein and Andrew, 2012; Savas, 2000). The public sector in Organisational for Economic Cooperation and Development (OECD) countries was too unwieldy and cumbersome to react in a coherent and measured way to the oil price hikes and the related stagflation of the 1970s. At first, the relatively large size of the public sector was viewed as one major reason behind this failure and therefore the increase of private sector investment in the economy was believed to be a remedial necessity. This view was mainly influenced by the increasing belief that the private sector was more efficient and responsive than the public sector. Consequently, the public sector needed to be transformed into a more active and responsive entity to assist governments in their quest for sustained economic growth and social development (Harris, 2001; Hood, 1995a, 1995b; Hopwood, 1992, 2000; March and Olsen, 1989; Miller, 1992, 1994; Rkein and Andrew, 2012; Savas, 2000).

In this regard, many countries have adopted new forms of organisational design, such as privatisation and outsourcing, to "reduce the role of government and increase the role of other institutions of society in producing goods and services" (Savas, 2000. p.3). These new organisational designs have gained popularity as a remedy intended to help promoting economic growth and have raised a discussion about public versus private sector service provision. This discussion has even extended to management of the public sector itself. Public sector organisations had to reassess their management practices to become more accountable and efficient in their use of public sector resources (Ferlie at al., 1996; Funnell and Cooper, 1998). In this regard, the last two decades have seen a new wave of organisational designs which mirrored the ones used in the private sector. This new wave was referred to as the New Public Management (NPM) and was defined by the infusion of market principles into the government world (Savas, 2000) based on the justification that they can improve government performance (World Bank, 2000).

The emergence of the NPM has revealed several themes about the structuring of political and administrative relationships for service provision to the public. These themes are:

- Policy vs. administration: while government maintains the policy setting role and agencies get the implementation and administration role.

- Principal (owner) vs. agent: where the government becomes the principal as owner of agencies and agencies act as an agent on its behalf.

- Purchaser vs. provider: where the government plays the role of a purchaser of agencies' goods and services, and agencies have the responsibility as a provider to provide the goods and services within the agreed requirements. 
- Input vs. outputs and outcomes: the focus of governments became shifted from input to outputs and results achieved as outputs and outcomes.

- Contestable vs. non-contestable markets: by subjecting government's agencies to competition so that they become more cost conscious and improve their performance.

- User pay vs. tax funding: in increasing competition, governments tended to minimise its subsidies and introduce user-pay charges that are cost reflective.

- Centralisation vs. decentralisation: governments tended to take a decentralised approach as it was believed that efficiency would be improved.

- Management from on high vs. managerial autonomy: governments also tended to decentralise the decisionmaking process by giving managers at different levels the autonomy of their management.

- Public vs. Private Sector: underlying all of the above, many discussions have arisen as to what services can better be provided under government control and what services should be moved to the private sector.

The adoption of these themes by governments reflected a commercial orientation, in the management of the public sector, in which governments believed that competition plays a major role in improving organisational performance. Governments believed that by subjecting organisations to competition they would become more cost conscious and results focused, leading to increased efficiency, effectiveness, and accountability (Hood, 1995a, 1995b; Hopwood, 1992, 2000; March and Olsen, 1989; Miller, 1992, 1994; Savas, 2000).

This study, however, explores the public sector reform within the ideals of NPM in a unique and special context characterised by a non-competitive market. Therefore, this study examines the developments of NPM themes in the context of the Northern Territory (NT) of Australia, in the process of reforming its public sector. The NT provides an ideal example for the purpose of this study as its economy is characterised by its small private sector and its limited competitive market. It is therefore likely to be interesting to see the workings of the NPM in a noncompetitive market.

The background to the non-competitive market situation arises with four locational features in the Northern Territory. First, the Northern Territory accounts for around one sixth of the total area of the Australian continent, and it covers a vast geographical area of 1,300,000 square kilometres. The result is a diverse mix of climates, landscapes, peoples and attractions. The population of the NT is approximately 204,500 people (Australian Bureau of Statistics, 2005). The Territory is sparsely populated with a density of 0.01 persons per square kilometre with $1 \%$ of the total population of Australia live on approximately the sixth of the total land mass.

Second, the relatively small and widely dispersed population has made the NT economy more reliant on financial help from the Commonwealth Government. The NT continues to obtain a relatively large share of the pool of Commonwealth revenue assistance, reflecting the fiscal disadvantages linked with its small population (NT Treasury, 2008).

Third, due to the relative absence of the private sector, the public sector became necessarily a key contributor to a range of industries in the NT economy, including education, defence, health and community services (NT Treasury, 1999, 2008). Compared to the rest of Australia, the public sector in NT is a significantly larger component of the economy than in most other jurisdictions as it accounted for about 33.7\% of State Final Demand in 2004-05, where nationally this figure is around the $21 \%$ (NT Treasury, 2006).

Fourth, until 1978, the Territory's administration had a colonial nature that was a direct result of the fact that responsibility resided with the Commonwealth government in Canberra. Various Commonwealth Government departments managed aspects of that responsibility and agents, acting on behalf of successive governments, interpreted federal acts and their associated policies as they applied to the Territory. Departmental directors had absolute control over the interpretation and implementation of policy and programmes, and they did not usually discuss issues with local NT stakeholders. So the management style found in the Territory prior to the 1980s was modelled on the type of bureaucratic dictatorship that was popular in the nineteenth century and intruded into the Territory through the agency of various state and commonwealth governments until self government was granted in 1978 (Hawkes and Moir, 1997).

\section{Institutional pressures towards organisational change}

This study seeks to examine the organisational change that occurred in the NT public sector, especially as it relates to the adoption of NPM. In order to address this issue, this study draws on a multi-perspective approach, which uses insights from different theories, namely: organisational theory, legitimacy theory, institutional theory and the technical rational choice model. Given the widespread view that no single theory is capable of fully explaining the complexity and subjective nature of organisational practices (Feyerabend, 1978, 1990; Latour, 1999), 
such an integrative framework helps us to develop an understanding of how and why particular organisational systems were implemented and the implications of their implementation. In recent years, these theories have been used in the public sector literature (see, eg. Brignall \& Modell, 2000; Carruthers, 1995; Czarniawaska \& Wolff, 1998; Edwards et al., 1995; Hoque \& Moll, 2001; Miller, 1994). It is recognised here that these theories are not the only, or even necessarily the superior, theoretical approaches. However, they offer insights which are helpful for understanding and conceptualising organisational change in the subject public sector.

The starting point in the integrative framework is the recognition that organisational systems and practices do change, but the drivers of the change and the responses to it differ from one to another. This change can occur as a response to external pressures (i.e., competition, professional groups, technology, customers) or internal pressures (need for efficiency, professionalism, a change in the power dynamics of the organisation, change in the size and complexity of the organisation, pursuit of organisational strategies) (Carruthers, 1995; Lawrence, 1999; Scott, 1998). Moreover, change can occur as a result of multiple pressures (including compliance with legal requirements, economic rationality, accountability, compliance with community expectations, and legitimacy) (Deegan, 2002). Throughout this study organisational changes are depicted as complex activities that are influenced by many internal and external factors to the organisation, and so the purpose of using multiple theoretical aspects is to take advantage of their complementariness (Ansari \& Euske, 1987; Hoque et al, 2004).

From the technical rational choice model, it can be argued that change in public sector accounting was believed to improve the decision-making process of various public sector organisations by changing the nature and quality of information generated from the accounting practices and techniques (Broadbent \& Guthrie, 1992; Guthrie et al, 1999; Hoque et al, 2004).

In addition, legitimacy theory takes the view that organisations are both influenced by and can influence the society in which they operate (Deegan, 2002). Legitimacy theory suggests that the motivation for change in organisational practices might be to bring legitimacy to the respective organisation and so it focuses on the social contract that exists between the organisation and society (Deegan, 2000). Such a contract is believed to represent the expectations of society. Legitimacy theory implies that organisations may change and adopt the norms of society to appear legitimate to that society (DiMaggio \& Powell, 1983, 1991; Meyer \& Rowan, 1977).

Institutional theory offers insights into organisation-environment relations and the ways in which organisations may react to institutional pressures. In this regard, Oliver (1991) has identified different strategic responses that organisations follow as a result of the institutional pressures that are exerted on them. She suggested that organisational responses will "vary from conforming to resistant, from passive to active, from preconscious to controlling, from impotent to influential, and from habitual to opportunistic, depending on the institutional pressures toward conformity that are exerted on organisations" (Oliver, 1991, p. 151).

The newly elected government in 1978 saw that the colonial-type administration was not suitable any more for the Territory (NT Treasury, 2006). Especially when the public expected this government to be responsive and to provide opportunities for the constituents in the electorates to have input to policy and budget guidelines set by Cabinet or by the Commonwealth. Since then, governments in the NT have embarked on reforming the public sector (NT Treasury, 2008).

Since 1978, the NT Government has faced the challenge of managing its economy and more specifically its public sector more efficiently. The isolation, the dispersion of its population and the demography of the Territory have all made it challenging to the Government in providing a state-like level of services compared with the rest of Australia. These factors have made the NT suffer from fiscal disadvantages in providing services to the community. The small and highly dispersed population has made the cost of providing services very high which made the Government more depended on Commonwealth grants than the states (NT Treasury, 1999, 2000). This resulted in making the Territory vulnerable to changes in Commonwealth policy and especially subject to pressure from the Commonwealth through the imposition of any condition that could be associated with those grants. This volatility is evidenced by the considerable slash in Commonwealth grants experienced in the mid 1980s (NT Treasury, 2000).

In addition, the public sector in the NT does not have the ability of its counterparts in other jurisdictions to generate its own revenues (NT Treasury, 2000). In the first fifteen years since self government was granted, expenses were significantly higher than revenues, largely because the Government had to spend large amounts on infrastructure and because of the limited revenues generated in the Territory during that time (NT Treasury, 2000).

All these reasons have forced consecutive NT governments to design policies that aimed to reduce expenses and cut costs and also at increasing revenues wherever possible in a way that decreases their dependence and reliance on Commonwealth grants. But public sector expenditure still accounted for over $40 \%$ of the State Final Demand, which meant that the performance of the economy as a whole might be limited by the large public sector and the small private sector (NT Treasury, 2000, 2006, 2008). 
Public sector agencies were poorly managed, and they regularly exceeded their budgets and spent any surplus balances at the end of each year in order to avoid future budget cuts. Thus the objective of the NT Government was to create an efficient public sector that was responsive to the strategic direction of the Government and improve the overall quality of services delivered (NT Treasury, 2000).

\section{Organisational responses towards NPM}

The aim of reform in the public sector in the NT led to a new range of processes through which transferable activities from government to the private sector were identified. This was based on the premise that such activities should be transferred because private sector organisations are more efficient than their counterparts in the public sector (Hoque and Moll, 2001). In this regard, consecutive governments in the NT have initially chosen two types of organisational designs: the 'privatisation' of the ownership of businesses and 'outsourcing' or 'contracting out' the provision of certain goods or services on behalf of government (NT Treasury, 1996, 2000, 2006, 2008).

\subsection{Privatisation}

Privatisation has become a popular course of action for the NT Government to raise funds and also as a response to the national and global belief that privatisation provided an opportunity to transfer risks to the private sector and the potential for improved business efficiency (NT Treasury, 2000). In doing this, the Government intended to switch its role from being an owner to being a regulator (Alam, 1997; Hoque and Hopper, 1994, 1997; Martin and Parker, 1995; Parker and Bradley, 2000; Sarker, 2006).

The Territory's first experience with privatisation was in 1982 with the sale of the Mount Wells Mining Battery (Aussie Heritage, 2015). Other examples followed with the sale of the Government Mining Laboratory in 1984; gas pipelines in 1983 and 1986; the power transmission line in 1988, the Pine Creek Power Station in 1990, and the Ayers Rock Resort sale in 1993. Also, in 1998, a comprehensive review had recommended the privatisation of the NT off-course betting business known as TAB (Totalizator Agency Board). The Government was interested in such privatisation because it realised that operational efficiencies were more likely to be extracted from the business through private ownership. Such a privatisation brought to the Government an up-front return together with an ongoing income stream in the form of taxation receipts (NT Treasury, 2000).

All these examples of privatisation were small in terms of their revenue size and did not have a major impact on the economy. In addition, consecutive NT governments have not privatised any of the major functions or public utilities (transport, water and electricity) because the lack of interest from the private sector as the NT is characterised by a number of small, isolated communities that have very poor economies of scale and a high cost of service delivery. And unless there is an income stream that makes an investment profitable, then private sector investment is likely to be limited, and this seems to be the case in relation to most NT government activities. The regional and remote areas that characterise the NT means that most services will need to be provided by government because the level of utilization will be too low for the investment to be of interest to the private sector.

\subsection{Outsourcing}

Outsourcing involves the government contracting for the provision of a third party to perform services to it on its behalf (Reilly and Tamkin, 1996). The NT Government realised an opportunity for cost savings in accessing the provision of some of its services from service providers who specialise in a particular service. Moving into purchasing the services instead of providing them directly can encourage economic development by stimulating private sector employment (Barrett, 1997). This was particularly needed in the Territory to increase the size of the private sector.

In 1997, Government decided to contract out the provision of its legal services that had been provided by the Attorney-General's Department. This decision was in accordance with the Government's interest to develop its local economy through the contribution of a developed local legal private profession, in addition to cost saving and quality of legal advice resulting from private provision (NT Treasury, 2006). And so in year 2000, a reviewing assessment of legal services private provision indicated that outsourcing government legal services has enabled the local private profession to consolidate its skills and to double in size and becoming able for the first time to compete with legal services providers outside the Territory. This in turn promised NT University graduates additional working opportunities at the end of their legal studies (NT Treasury, 2008).

In 1998, the Government decided to outsource all information technology and telecommunications (IT\&T) services (desktops, helpdesk services, mainframe services, and internet telecommunications networks, etc...). The Government has aimed through this decision to advance the IT\&T industry by improving its capability and capacity and by driving some cost efficiencies through the provision of the services by leading expert private sector companies. In addition, the expansion of the local industry would result in stimulating economic growth and job creation (NT Treasury, 2000). 
In 1999 The Government realised that the market for superannuation funds is large and that private superannuation funds offer employees high returns and low charges. The Government questioned the need to continue managing a service that is offered by private providers and it decided to outsource the provision of employer superannuation so that it can focus on other core Government activities (NT Treasury, 2000).

Despite all of these privatisation and outsourcing activities, the appetite for them has remained limited and of a small scale. The relatively small and dispersed markets have made the cost of service delivery much higher and deterred private investments away from the Territory. Overall, privatisation and outsourcing were not able to significantly increase the private sector business investment contribution, and so the NT Government had to find additional processes to improve the performance of the public sector.

\subsection{National Competition Policy and organisational reform}

The small size of the privatised and outsourced projects and activities has limited the intended objective of privatisation and outsourcing in significantly introducing competition into the NT (NT Treasury, 2000, 2006). And so, by the year 1990, the NT Government still owned most of the economic infrastructure, including hospitals, universities, schools, mines, postal services, insurance and electric power. Hence, the NT Government started to introduce new market-based practices into its public sector agencies, such as the Public Sector Employment and Management Act that was introduced in 1993 and which incorporated a range of NPM reform principles, such as devolution of responsibility, performance management and accountability.

Also in 1995, the NT Government accepted the three principles of the National Competition Policy (NCP): the Conduct Code Agreement, the Competition Principles Agreement (CPA) and the Agreement to Implement National Competition Policy and Related Reforms Revision (Hoque and Moll, 2001; NT Treasury, 1996). The NCP was considered, by all governments in Australia to be the major catalyst behind public sector reform because, in a market-based economy, it is expected that competition plays a major role in generating productivity and cost efficiency improvement. So, in this regard, the Territory has committed to remove organisational hindrances that restrain competition. Hence, a legislation review has taken place in 1996 (NT Treasury, 1996).

\subsubsection{Competitive neutrality}

The principal implication of the National Competition Policy (NCP) on government entities was that they cannot demonstrate any anti-competitive conduct. The Competition Principles Agreement (CPA) required the NT and the states to develop a competitive neutrality policy which was defined as "the elimination of resource allocation distortions arising out of the public ownership of entities engaged in significant business activities: government businesses should not enjoy any competitive advantage simply as a result of public sector ownership" (NT Treasury, 1996, p.100). Examples of such advantage may include: discounted interest rates; guarantees on debts; regulatory preference; and tax exemptions (Hoque and Moll, 2001; McTaggert, 1996; NT Treasury, 1996). The Independent Committee of Inquiry (1993, p. 297) stated that where these disparities exist, there is a "potential to reduce economic efficiency and community welfare by distorting the allocation of resources". Without competitive neutrality the "society's resources are not being put to their best use" (Hilmer et al., 1993, p. 297). So the NT Government aimed to remove advantages occurring as a result of government ownership, and introduced measures to ensure that government businesses compete on equal terms with private businesses (Girle, 2004).

\subsubsection{Corporatisation and commercialisation}

The primary response of the NT Government to its competitive neutrality commitments has been reflected in the new Financial Management Act (1995) which distinguished between the Government's general activities and its more commercially-oriented business activities. So the NT Government established Government Business Divisions (GBDs) to reflect the commercial focus of those government businesses.

The separation of NT Government businesses has led to development of commercially-oriented operational policies, for GBDs, that are not appropriate for government's general non-business activities. Through this, the Government aimed to create a commercial performance framework for the purpose of improving performance management and generating additional efficiency and productivity growth. Within this framework, the following commercial practices were implemented (NT Treasury, 1999):

- Commercial accounting practices, with GBDs required to prepare financial statements on accrual basis rather than cash basis.

- Full cost attribution, with GBDs required to pay the full costs of service provision including corporate overheads, superannuation costs, the cost of leasing premises, and auditing and legal costs.

- Full cost-reflective pricing, with GBDs pricing their services based on the actual costs of their provision. The prices are reviewed by Treasury and approved by Cabinet.

- Performance reporting, with GBDs reporting their financial and non-financial performance in their annual reports. 
These means were believed to facilitate efficiency improvement for GBDs by making them pay the full accrual cost of the used resources, and then charging cost reflective prices with some marginal gain. This was believed to improve the efficiency by which resources are allocated to both the production (by GBDs) and consumption of services (by customers) (NT Treasury, 1999, 2000, 2006).

The corporatisation approach that was adopted in the NT was only to corporatize large GBDs, Darwin Port Authority, Territory Insurance Office, and the Power and Water Authority. Each of these entities was given a separate legal entity via legislation and was supported by a corporate governance structure that is based on competitive neutrality, managerial autonomy, and effective performance monitoring by the Government as owner.

The CPA did not require all business activities to be corporatized and so the NT government has assumed a path of commercialisation rather than corporatisation for the other GBDs because of their small size. After all, subclause 3 (5) (b) of CPA states that competitive neutrality is required only when the benefits from implementation outweigh the costs (NT Treasury, 1996). Commercialisation was a preliminary step before the full corporatisation of a specific business by changing it into a real non privatised business entity or what the NT government calls a Government Owned Corporation (GOC).

The NT Government wanted to change GBDs into real business entities or GOCs based on the revenue of that business (NT Treasury, 2000). If the GBD receives most of its revenue from the provision of services to a large number of external, non government, customers, then it is more likely to be driven by market constituents and to be more responsive to improve the quality of its services and cost structures. Hence, that business is suited to become a GOC. By contrast, a government business that generates a considerable portion of its income from the Government, in the form of subsidies, is unlikely to benefit from the application of the commercial-business model. This means that if the business is operating in a competitive market, the need for it to be responsive to competitive pressures and to operate under competitive neutrality by giving it freedom of operations and autonomy, is more desirable. Hence, competition provides an improved setting for government businesses to function under a business-like structure.

\subsection{Working for Outcomes framework and output reporting}

In its pursuit for reform the NT Government continued its adoption of the NPM practices and in 2002 it introduced the Working for Outcomes (WFO) framework. The intention was to help public sector agencies to operate like private sector entities. A major component of the WFO framework was output reporting which encompasses performance reporting that is based on outputs and outcomes. This emphasized the Government's direction to become a results-oriented government by shifting the focus from budget control to results and outcomes achieved. In this regard, the WFO framework aimed to provide an improved basis for resource allocation and to discharge agencies accountability for their performance against the results that they were funded for and achieved.

Ideally, under output reporting in the NT, the Government would specify, via outcome statements, the outcomes it is aiming to accomplish in given areas which generally reflect its objectives. These outcomes are generally specified in terms of the impact the Government is seeking to have on its community for example, one of the outcomes in health is "to improve the health and wellbeing of those in the Northern Territory who require acute or specialist care" (NT Treasury, 2003, p. 197). Another example from another agency is "cost-effective corporate services for Government agencies" (NT Treasury, 2003, p. 197). To achieve Government objectives and fulfil its policies, the Government and its agencies would then set a list of the best possible outputs that lead to the achievement of these outcomes and then cluster them in separate groups called 'output groups' where each group represents a segment of each agency's activities. In addition, the Government and agencies would set for each output a range of performance measures or benchmark indicators in terms of quantity, quality, cost and timeliness. These measures are the output characteristics that agencies are funded to achieve. Later, agencies are required to report their performance against these performance indicators. This reporting is intended to take place in both the agencies' annual reports, and in the Treasurer's annual reports for the whole of government level.

At the whole of government level, the review of the Treasurer's annual reports showed that they are constituted of financial information only and they do not include any performance reporting about what the Government as a whole has achieved towards its objectives. A Treasury executive explained that actual performance is reported for individual agencies separately and takes place as a part of their annual reports. The review of several annual reports in the NT showed that agencies' annual reports maintain the same output-outcome structure that is outlined in the budget and they only report their performance against output performance measures stated in the budget (quantity, quality, cost and timeliness). Agencies in their annual reports do not report on how their performance has impacted on outcomes or Government objectives. The Treasurer's annual reports for the whole of government show only how the Government performed against its budget outcome in terms of its deficit or surplus. A Treasury Executive explained that no outcome reporting takes place in the NT because the "relationship between outputs and outcomes is still very fragile". 
Although most interviewees acknowledged the importance and significance of output and outcome reporting they all stated that its contribution could only be achieved if Government specified measurable outcomes and outputs that directly relate to goods and services provided by agencies. Currently agencies' outputs are very broad and general. For example, some of one agency's outputs are 'financial and accounting services', 'human resource services', and 'property management'. It is clear that these outputs are very general and do not relate directly to the services provided, going closer to the service provided would offer a much clearer output that can be compared with the same service provided by another provider. The service provided to clients is generally the one that gets costed and priced and subsequently sold, and not the segment of the business that produces the service. For example, if the above agency has 'invoice processing' as an output, given that it is a direct service, this would offer a much more informative output definition than 'financial and accounting services' which is basically a division more than it is an output. Overall, it is suggested that each output should be the service that is provided and specified as clearly as possible.

In addition, interviews and the analysis of agencies' annual reports showed that reporting against performance measures has not been used to discharge agencies' accountability as intended. Several agencies' directors explained that Government or parliamentary committees never resorted to outputs performance measures to hold agencies to account. Instead, they generally take it for granted that the agency is responsible for the objectives and discuss their merits in terms of generally accepted performance standards, without reference to stated output measures. For example, one director stated that "these measures are not used to judge the performance of agencies, and neither do they affect the appropriation process", and another director expressed the view that "they were just used for illustrative purpose only, by saying these are our budget performance measures, and this is how we actually went against them". Interviewees referred the failure of output reporting as a framework to improve performance and discharge accountability, to the non-competitive market these agencies are operating in. After all, agencies are not being funded on the basis of actual outputs produced, but on the total overall need to deliver their services. In the absence of private sector providers, government agencies were still socially responsible to deliver their services and respond to community needs irrespective of the budgeted performance measures. Hence, output reporting has been superficial and it did not reflect the actual performance of agencies.

\section{Conclusion}

The pursuit of public sector reform by governments around the globe has been driven by the NPM ideals and by the belief that competition drives efficiency and effectiveness into public sector organisations. However, the concept of the NPM was developed in the private sector and its benefits were explained in terms of its usefulness in costing, pricing and better decision making, that are positively stimulated by the contestability in the market. Whereas extant literature focuses on issues relating to NPM and its implications in the public sector in general, an understanding of its workings in a non-competitive market is fundamental to policy makers and to enrich the literature.

The reform of the public sector in the NT had its domestic reasons but was actually part of a national movement driven by a number of national and global factors. Globalization and other social, economic and financial pressures have forced the NT Government to embark on reforming its public sector. The workings of NPM reform were not of the same significance as in the rest of the states because of some unique characteristics of the NT environment, such as small economy, comparatively large public sector, small private sector, and small and highly dispersed population. The small economy and the large public sector made the NT Government rely more on Commonwealth grants as a major source of revenues, and the small private sector resulted in an insignificant level of competition.

The study showed that the adopted NPM practices has overall been limited in the context of a non-competitive environment. Privatisation and outsourcing did not achieve their intended objectives in creating a more competitive environment and increasing the size of the private sector in order to improve performance. This was mainly because private investors did not have an appetite for investment in a market that has very poor economy of scale and high cost of service delivery resulting from a small, isolated, and dispersed population. The study showed that, in such environment, service delivery to the public remains a social responsibility of the government irrespective of the economic viability. In addition, the study showed that the Government did not use output reporting to adjust agencies funding or to discharge their accountability.

Finally, it is noted that the adoption of NPM practices in a non-competitive public sector has been mainly driven by legitimacy pressures to imitate private sector management practices and other public sectors that had adopted them. The study showed that the Government justified its introduction of the NPM on the basis of rationalizing public sector management, as it was believed to lead to enhance decision-making process and improve efficiency, effectiveness and accountability but the reality was far from satisfactory. 


\section{References}

Alam, M. (1997). "Budgeting Process in Uncertain Contexts: A Study of State-Owned Enterprises in Bangladesh", Management Accounting Research, Vol. 8 No.1, pp. 147-168.

Ansari, S. L., \& Euske, K. J. (1987). Rational, rationalizing, and reifying uses of accounting data in organizations. Accounting, Organizations and Society, 12(1), 549-579.

Aussie Heritage, (n.d). Retrieved September 2015, from http://www.aussieheritage.com.au

Australian Bureau of Statistics (2005). Australian Demographic Statistics. No. 3101.0, Australian Bureau of Statistics, Canberra.

Barrett, P. (1997). "Corporate governance - PS style". Australian Accountant, Vol. 67 No.7, pp. 30-31.

Brignall, S., Modell, S. (2000). An institutional perspective on performance measurement and management in the 'new public sector'. Management Accounting Research, 11(1), 281-306

Broadbent, J., \& Guthrie, J. (1992). Changes in Public Sector: A Review of Recent 'Alternative' Accounting Research. Accounting Auditing and Accountability Journal, 5(2), 3-31.

Carruthers, B. C. (1995). Accounting, Ambiguity, and the New Institutionalisation. Accounting, Organizations and Society, 20(4), 313-328.

Czrniawska, B., \& Wolff, R. (1998). Constructing New Identities in Established Organization Fields. International Studies of Management and Organization, 28(3), 32-56.

Deegan, C. (2000). Financial Accounting Theory. Roseville, NSW: McGraw-Hill.

Deegan, C. (2002). The legitimising effect of social and environmental disclosures - a theoretical foundation. Accounting, Auditing and Accountability Journal, 15(3), 282-311.

DiMaggio, P. J., \& Powell, W. W. (1983). The iron cage revisited: Institutional isomorphism and collective rationality in organizational fields. American Sociological Review, 48(2), 147-160

DiMaggio, P.J. \& Powell, W.W. (1991). Introduction. In W.W. Powell, \& P.J. DiMaggio (Eds), The New Institutionalism in Organizational Analysis (pp. 1-40). Chicago: The University of Chicago Press.

Edwards, P., Ezzamel, M., Robson, K., \& Taylor, M. (1995). The Development of Local Management of Schools: Budgets, Accountability and Educational Impact. Financial Accountability and Management, 11(4), 297315.

Ferlie, E., Ashburner, L., Fitzgerald,L., and Pettigrew, A. (1996). The New Public Management, Oxford University Press, New York.

Funnell, W. and Cooper, K. (1998). Public Sector Accounting and Accountability in Australia, University of New South Wales Press, Sydney.

Girle, A. (2004). "Commercialisation of state government legal services". Australian Journal of Public Administration, Vol 63 No.3, pp. 53-59.

Guthrie, J., Olson, O., and Humphrey, C. (1999). "Debating Developments in new public financial management: the limits of global theorising and some new ways forward". Financial Accountability and Management, Vol. 15 No. 3/4, pp. 209-228.

Harris, L.C. (2001), "Market orientation and performance: Objective and subjective empirical evidence from UK companies", Journal of Management studies, Vol. 38 No.1.

Hawkes, D. and Moir, K. (1997). "Australia's Northern Territory perspectives of public sector reform". Public Administration and Development, Vol. 17 No. 1, pp. 181-195.

Hilmer, F.G, Rayner, M.R. and Tapernell, G.Q. (1993). National Competition Policy: Report by the Independent Committee of Inquiry, Australian Government Printing Service, Canberra.

Hood, C. (1995a). "The 'New Public Management' in the 1980s: Variations on a Theme". Accounting, Organizations and Society, Vol. 20 No. 2/3, pp. 93-109

Hood, C. (1995b). "Controlling Public Management". Public Finance Foundation Review, No. 7.

Hopwood, A. (1992). "Accounting calculation and the shifting sphere of the economic". European Accounting Review, Vol. 17 No. 1, pp. 125-143

Hopwood, A. (2000). "Understanding Financial Accounting Practice". Accounting, Organisations and Society, Vol. 25 No. 8, pp. 763-766.

Hoque, Z. and Hopper, T. (1994). "Rationality, accounting and politics: a case study of management control in a Bangladeshi Jute Mill”. Management Accounting Research, Vol. 5 No. 1, pp. 5-30.

Hoque, Z. and Hopper, T. M. (1997). "Political and Industrial Relations Turbulence, Competition and Budgeting in the Nationalised Jute Mills of Bangladesh". Accounting and Business Research, Vol. 27 No. 2, pp. 125143.

Hoque, Z. and Moll, J. (2001). "Public sector reform: Implications for accounting, accountability and performance of state-owned entities - An Australian perspective". International Journal of Public Sector Management, Vol. 14 No. 4, pp. 304-326.

Hoque, Z., Arends, S., \& Alexander, R. (2004). Policing the police service: A case study of the rise of "new public management" within an Australian police service. Accounting, Auditing and Accountability Journal, 17(1). 
Independent Committee of Inquiry. (1993). National Competition Policy (Hilmer Report), Australian Government Publishing Service, Canberra.

Lawrence, T.B. (1999). Institutional Strategy. Journal of Management, 25(2), 161-188.

March, J. G. and Olsen, J. P. (1989). Rediscovering Institutions: The Organisational Basis of Politics, Free Press, New York.

Martin, S. and Parker, D. (1995). "Privatization and Economic Performance Throughout the UK Business Cycle". Managerial and Decision Economics, Vol. 16 No. 3, pp. 225-237.

McTaggart, D. (1996), National Competition Policy: A Queensland Perspective. CEDA Information Paper No. 49.

Meyer, J.W., \& Rowan, B. (1977). Institutionalised organizations: formal structure as myth and ceremony. American Journal of Sociology, 83(2): 340-363.

Miller, P. (1992). "Accounting and Objectivity: The Invention of Calculating Selves". Annals of Scholarship, Vol. 9 No. 1 , pp. 61-85.

Miller, P. (1994). "Accounting as social and institutional practice: an introduction", in Hopwood, A. G. and Miller, P. (Eds), Accounting as Social and Institutional Practice, Cambridge University Press, Cambridge, pp. 139.

NT Treasury (1996). 1996-1997 Budget. Northern Territory Government, Department of Treasury, Darwin.

NT Treasury (1999). 1999-2000 Budget. Northern Territory Government, Department of Treasury, Darwin.

NT Treasury (2000). 2000-2001 Budget. Northern Territory Government, Department of Treasury, Darwin.

NT Treasury (2003). 2003-2004 Budget. Northern Territory Government, Department of Treasury, Darwin.

NT Treasury (2004). 2004-2005 Budget. Northern Territory Government, Department of Treasury, Darwin.

NT Treasury (2006). 2006-2007 Budget. Northern Territory Government, Department of Treasury, Darwin.

NT Treasury (2008). 2007-2008 Budget. Northern Territory Government, Department of Treasury, Darwin.

Oliver, C. (1991). Strategic Responses to Institutional Processes. Academy of Management Review, 16 (1), 145 179.

Olson, O., Guthrie, J. And Humphrey, C. (1998). Global Warning: Debating International Developments in New Public Financial Management, Cappelen Akademisk Forlag, Oslo.

Parker, R. S. and Bradley, L. (2000). "Organizational culture in the public sector: evidence from six organizations". The International Journal of Public Sector Management, Vol. 13 No. 2, pp. 125-141.

Reilly, P. and Tamkin, P. (1996). Outsourcing: A Flexible Option for the Future?, Institute of Employment Studies, Brighton, UK.

Rkein, A. and Andrew, B. H (2012). "Public sector commercial orientation and the social contract: a study of performance management in a non-competitive environment". Pacific Accounting Review, 24 (3), 292-313.

Sarker, A.E. (2006). "New public management in developing countries: An analysis of success and failure with particular reference to Singapore and Bangladesh". International Journal of Public Sector Management, Vol. 19 No. 2, pp. 180-203.

Savas, E. S. (2000). Privatization and public-private partnerships, Cornell University Press, Ithaca, NY.

Scott, W. R. (1998). Organizations: Rational, Natural, and Open Systems. London: Prentice-Hall Inc.

World Bank. (2000). World Bank Development Report: Attacking poverty, Oxford University Press, New York. 